\title{
Seán Dunne's The Road to Silence: An Anomalous Spiritual Autobiography?
}

James S. Rogers

\section{Q OpenEdition \\ 1 Journals}

\section{Electronic version}

URL: http://journals.openedition.org/etudesirlandaises/3972

DOI: 10.4000/etudesirlandaises.3972

ISSN: 2259-8863

\section{Publisher}

Presses universitaires de Rennes

\section{Printed version}

Date of publication: 20 November 2014

Number of pages: 115-126

ISBN: 978-2-7535-3559-6

ISSN: 0183-973X

\section{Electronic reference}

James S. Rogers, "Seán Dunne's The Road to Silence: An Anomalous Spiritual Autobiography? », Études irlandaises [Online], 39-2 | 2014, Online since 20 November 2016, connection on 01 May 2019. URL : http://journals.openedition.org/etudesirlandaises/3972 ; DOI : 10.4000/etudesirlandaises.3972 


\title{
Seán Dunne's The Road to Silence: An Anomalous Spiritual Autobiography?
}

\author{
James Silas Rogers \\ University of St Thomas, St Paul (MN)
}

\begin{abstract}
In many ways, The Road to Silence, the slim second volume of autobiography by the Corkbased poet Seán Dunne, conforms to the "circular" pattern of spiritual biography as theorized by David Leigh and other critics. This article argues that this is one of several ways that Dunne's memoir can profitably be read as an intertext with Augustine's Confessions. However, Dunne's book differs markedly from many of the conventions of both classic and contemporary spiritual autobiographies. Prominent among these differences are its brevity; its dispassionate tone; and the manner in which it scrupulously maintains a distinction between the author's interior life and his life in the world.

Keywords: Seán Dunne (1956-1995), spiritual biography, Ireland; Irish poets (20 $0^{\text {th }}$ century), biography, monastic and religious orders, spiritual life, autobiography, religious aspects.

\section{Résumé}

The Road to Silence, le mince second volume autobiographique du poète résidant à Cork, Seán Dunne, se conforme de bien des manières au schéma "circulaire" de la biographie spirituelle telle que théorisée par David Leigh et autres critiques. Cet article défend ainsi l'idée que l'une des multiples façons de lire les mémoires de Dunne est de le faire en perspective intertextuelle avec Les Confessions de saint Augustin. Cependant, le livre de Dunne prend nettement ses distances vis à vis de multiples conventions du genre autobiographique à la fois classique et contemporain. Il se distingue en particulier par sa brièveté, son ton dénué d'émotion et la manière dont il établit scrupuleusement une distinction entre la vie intérieure de l'auteur et sa vie dans le monde.

Mots clés: Seán Dunne (1956-1995), biographie spirituelle, poètes irlandais (XX' siècle), biographie, ordres religieux et monastiques, vie spirituelle, autobiographie, aspects religieux
\end{abstract}

To the extent that Seán Dunne, the Cork-based poet, critic and journalist who died in August 1995 of heart attack at age thirty-nine, is remembered today, it is as a poet - one of the many Irish poets whom the critical community knows is there, but about whom few read and even fewer write. Born in Waterford in 1956, Dunne was one of the group of writers who studied under Seán Lucy and John Montague at UCC, and his three collections - Against the Storm (1985), The Sheltered Nest (1992), and Time and the Island (1996) - were well received 
at the time. His Collected Poems was published by the Gallery Press in a posthumous volume in 2005. In Waterford, he is remembered by the Seán Dunne Young Writers Award, presented at the annual writers' festival. Dunne's work is considered briefly in a number of surveys, and there is a fine short memoir of him in Thomas McCarthy's Gardens of Remembrance (1998). Yet the MLA Bibliography lists no critical articles that treat of Dunne and his work.

Dunne also wrote two autobiographies, and he wrote them when young. Before he died so prematurely, he had published In My Father's House in 1991, which is a straightforward account of growing up in a working-class family in the housing estates of Waterford. Three years later, he published The Road to Silence: An Irish Spiritual Odyssey. This article considers the second of these autobiographies. In many ways, Road to Silence fulfils most readers' expectations of a spiritual autobiography, a genre that has also attracted a considerable level of critical attention in recent decades ${ }^{1}$. In other ways, notably its brevity and in the manner in which the author maintains a strict division between his inner life and his life in the world, Dunne's modest little book stands apart from virtually all contemporary works in the genre ${ }^{2}$. For one thing, Dunne recounts his "spiritual odyssey" in only seventy-nine pages. In contrast, most editions of Thomas Merton's famous account of Trappist life, The Seven Storey Mountain, run to more than 400 pages. Other well-known recent accounts of contemplative life are Sarah Maitland's $A$ Book of Silence (2010) and Kathleen Norris's The Cloister Walk (1997), each of which is four to five times lengthier than Dunne's account.

But the text itself also defies expectations. Stylistically, one aspect of Road to Silence that a contemporary reader will find unusual is its employment of unexpectedly formal, and often somewhat pedestrian, language. Although Dunne has a poet's gift for the occasional striking metaphor, the fact is that in this book - unlike In My Father's House, and even more unlike his poetry - he writes with a studied quality of detachment, a willed plain-spokenness. Nowhere is this more clear than in its opening sentences:

1. See especially David J. Leigh, Circuitous Journeys: Modern Spiritual Autobiography, New York, Fordham University Press, 2000. Leigh's theorizing of the genre of spiritual autobiography is, to my mind, definitive. Other recent works on the topic include Wesley A. Kort, Textual Intimacy: Autobiography and Religious Identities, Charlottesville, University of Virginia Press,2012; John D. Barbour, Versions of Deconversion: Autobiography and the Loss of Faith, Charlottesville, University of Virginia Press, 1994; and John Neary, Shadows and Illumination: Literature as Spiritual Journey, Eastbourne, Sussex Academic Press, 2011.

2. Spiritual autobiography is no longer "ghettoized" in religious publishing houses. Recent memoiristic religious books that have crossed into mainstream publishing success and become bestsellers include Kathleen Norris, Dakota: A Spiritual Geography, New York, Houghton Mifflin, 2001; Tony Hendra, Fr. Joe: The Man Who Saved My Soul, New York, Random House, 2004; and Elizabeth Gilbert, Eat Pray Love, New York, Penguin, 2006. For an example of a religious autobiography that became a bestseller, it would still be hard to top Thomas Merton's The Seven Storey Mountain (1948), which after an initial print run of only 7,500, sold 600,000 copies in its first year, and millions more since. 
As a child, I saw the world with a religious dimension that I have never lost. At its most negative, this consisted of a morbid fear that punishment would ensue if I broke the rules of Catholicism. There were times when I felt that a dreadful punishment would follow if, say, I murdered someone, but even if I stole an apple from a classmate's schoolbag ${ }^{3}$.

The stiltedness of the prose leaps out: this is not the language of a poet. Throughout The Road to Silence, one gets the feeling that Dunne employs an attimes wooden style - in such constructions as "a morbid fear that punishment would ensue if I broke the rules of Catholicism" - as a sort of shield from the rawness of experience itself. The book is very much an intellectual narrative. For a contemporary reader, attuned to the confessionalism of such spiritual memoirs as Anne Lamott's Traveling Mercies (1999) or even to the discretely told, but nonetheless juicy, accounts of Thomas Merton's early life, Dunne's language feels cerebral and remarkably dispassionate. One could easily believe that it is a translation. Not just any translation, but the translation of an ancient text the same sort of language that one finds reading Augustine's Confessions. Dunne subtly alludes to Augustine with his reference to stealing an apple. The apple both invokes the Fall itself and suggests the extraordinarily scrupulous passage of Augustine's Book II, in which he meditates on the evil of stealing unripe pears.

This is the first of many ways in which Augustine insinuates himself into Dunne's narrative. The fourth-century author of the Confessions is never mentioned in the text, yet Augustine's template for the writing of one's spiritual life is everywhere to be felt - as, indeed, it is for all spiritual autobiographers; the saint has been called the inventor of the genre, and beyond that, the "inventor of the inner self 4 ". There are, of course, dramatic differences in their narratives, not the least of which is that Dunne appears to share none of Augustine's repudiation of the flesh, and little if any of the saint's conviction of his own sinfulness. Yet the affinities are there. Augustine wrote that he "had become to myself a vast problem 5 ", and so has Dunne; the memoir records his path toward resolving deep internal conflicts. Both men stand back and look for a cohering pattern in their personal stories - in Janet Varner Gunn's phrase, they are "reading" their own lives ${ }^{6}$.

3. Seán Dunne, The Road to Silence: An Irish Spiritual Odyssey, Dublin, New Island Books, 1994, p. 7. Subsequent page citations are given parenthetically in the text.

4. See, for instance, Patricia Hampl, "The Invention of Autobiography: Augustine's Confessions", in I Could Tell You Stories: Sojourns in the Land of Memory, New York, W.W, Norton, 1999, p. 166-183; Phillip Cary, Augustine's Invention of the Inner Self: The Legacy of a Christian Platonist, New York and Oxford, Oxford University Press, 2000.

5. Saint Augustine, Confessions, transl. Henry Chadwick, Oxford and New York, Oxford University Press, p. 57.

6. Janet Varner Gunn Autobiography: Toward a Poetics of Experience, Philadelphia, IUniversity of Pennsylvania Press, 1982, p. 5. 
This detachment probably traces back to the fact that Dunne was a journalist, a "vendor of words" as Augustine put it", who supported himself as freelance writer $^{8}$. The intentionally plain, intentionally removed tone of The Road to Silence suggests that what we are reading is in fact a journalist reporting on himself. But we are, for the most part, told about, rather than shown, the intensity of his spiritual anguish. This neutrality of tone is a particular failing of reporters' memoirs: as the New Yorker journalist Janet Malcolm observes, one "obstacle in the way of the journalist turned autobiographer is the pose of objectivity into which journalists habitually, almost mechanically, fall when they write. The 'I' of journalism is a kind of ultra-reliable narrator and impossibly rational and disinterested person ${ }^{9} . . . "$

Dunne's removal from the intensity of experience is likewise clear in his handling of a central event, the death of a parent. It is not easy to find an intact family in Irish autobiography, and Dunne's story is no exception; his mother died when he was four, and he was reared chiefly by his English housekeeper, Tessie. An early experience of death is common to many spiritual autobiographies - think of Augustine's loss of his friend, or of Merton losing both parents while still in his teens but in neither book does Dunne dwell on this trauma. In The Road to Silence, he acknowledges the event's far-reaching impact, but offers only this somewhat clinical comment: "I realise now that much of my intense involvement with religion as a child was connected with my mother, a devout woman who died when I was four and whose death became a wound that shaped me as a person and as a writer" (p. 8). Although the story would seem to invite pathos and deep introspection, we find few of those qualities in In My Father's House, and none at all in The Road to Silence; if this is a wound, it is a wholly intellectualized one ${ }^{10}$.

7. To be accurate, Augustine's famous phrase in Book IX of Confessions refers to the work of a rhetorician, not a journalist.

8. The generally disappointing quality of journalists' autobiographies - often the result of an intentional absence of interiority - is discussed by Dennis Russell in "The Journalistic Autobiography: How Reporters View Themselves and Order Their Experience", Studies in Popular Culture, volume 18, number 1, p. 83-92. Nevertheless, being a journalist is hardly an impediment to writing a spiritual autobiography: Dorothy Day, Thomas Merton, and Gandhi all worked as reporters. It is surely notable that two of the most admired spiritual autobiographers of modern Britain, Malcolm Muggeridge and Tony Hendra, were not just editors but editors of irreverent humor magazines, Punch and National Lampoon, respectively. A recent Irish example of a journalist turned spiritual autobiographer is the controversial and often pugnacious John Waters, Lapsed Agnostic, London, Continuum, 2007.

9. Janet Malcolm, "Thoughts on Autobiography from an Abandoned Autobiography", New York Review of Books blog, March 25, 2010, available at [http://www.nybooks.com/blogs/nyrblog/2010/mar/25/thoughts-on-autobiography-from-an-abandoned/] (Accessed 31 January 2014).

10. It is worth remarking, too, that, apart from the dedication to his partner Trish Edelstein, one could read The Road to Silence and never know that Dunne was in a long-term relationship and had a family of four. Then again, we never learn the name of the woman who was Augustine's mistress and the mother of his son either. 
The first book of autobiography ends, as many memoirs do, with Dunne realizing that he is at an axial moment, a point that is at once both the end of an enclosed childhood and the beginning of a larger life in the word. It closes thus:

The city was a background with which I had grown too familiar while the sky was a vast unknown... The train pulled out, gathering speed as it went past the river on the way to Rosslare, the rhythmic movement of its wheels gathering force as it sped.

It was time for me to get out as well ${ }^{11}$.

Memoirists, Irish and otherwise, spiritual and otherwise, often conclude the story of their early lives on moment of transformation. One thinks of the decisive moment in Frank O'Connor's first volume of autobiography, An Only Child, which ends "I had tossed my cap over the wall of life, and I knew I must follow it, wherever it had fallen" ${ }^{12}$. And in what is becoming the Ur-story of Irish childhood, Frank McCourt's Angela's Ashes, we find a similar recognition that the journey must now lead outward. Dunne's decision to tell his story in more than one book is not unusual. Multi-volume memoirs are common: think of Seán O'Casey's six volumes of autobiography published between 1939 and 1956, or for that matter, the consciously plural title of Yeats's Autobiographies. But such autobiographies generally frame the subject's life as a continuous, cohering story, however segmented into distinct parts it may have been. The authorial choice to end on a moment of decision implies that the next book, the next story, flows out of the first. The most striking anomaly of Dunne's autobiographical project, when viewed alongside most other contemporary writers, is that the second book remains entirely separate.

In The Road to Silence, the author immediately undermines any expectation that the second book is a continuation of the first, as its opening epigraph quotes Thomas Merton: "Our real journey in life is interior". The two books provide us with, in effect, two stories. In My Father's House gives us his life in its external contexts: school, the particularities of his time, and as signaled in the title, his family. The second book stands apart from the world by design: it is the story of a soul. Much of the second book takes place in the Trappist monastery and retreat center of Mount Melleray in County Waterford, where Dunne first went on a journalistic assignment, and which becomes a place of centering and origins for Dunne, a sacred geography. His characterization of the place provides a possible window on how he conceived of the autobiographical project: 
I learned that the place is not simply a set of buildings where monks live, pray and work. The monastic sense permeates the fields, the paths and the people who walk them [...]. I understood what the old Celtic monks meant when they spoke of two landscapes, one physical with its rocks and mountains, the other sacral and intensely connected with spirituality (p. 46).

In writing two autobiographies - a secular one and a sacred one, "the other interior story" - Dunne makes a division similar to that which he ascribes to the Celtic monastics. He segregates the world into two spheres, one concerned with the facts of his biography, and one that charts a parallel spiritual path. It is not unusual to encounter a sort of latent or implied platonism in the sort of popular Catholicism in which Dunne was raised, a division of the human person into spirit and flesh. What is unusual is to find this dichotomy so clearly expressed in a mature spiritual writer.

The Road to Silence is divided into seven numbered chapters, which can be summed up briefly and which bear many resemblances to the patterns of classic spiritual autobiography. That pattern has been described by David Leigh as a "circuitous journey": memoirists of the spiritual life follow "a general three-stage narrative pattern in which childhood events (stage one) raise questions that drive the author on a negative journey of wandering in a desert of illusory answers (stage two) before he or she discovers a transforming world in which the original questions can be resolved (stage three) ${ }^{13}$ ".

These patterns play our clearly in Dunne's story. The opening chapter conveys his profound sense of dividedness, his sense of standing apart from the world. He writes movingly of a childhood, and an entire Irish culture, that is ritually attuned to Catholic practice and the church calendar; his description of a Corpus Christi procession as "street theatre" (p. 10) imparts wholeness and sacramentality to the shabbiness of working-class Ireland. Part of the appeal of Catholicism in his early years is precisely its ability to make the transcendent real. He quotes Flannery O'Connor approvingly, citing her remark that "the Church is the custodian of the sense of life as a mystery" (p. 14). But immediately after this, he notes that, "Outside of such times, my sense of religion was dominated by terror" (p. 14).

Dunne follows the Augustinian model of "wandering" in the next chapter, when he describes his several efforts at trying on another belief system - but it is a sincere search, and not mere spiritual tourism. His yearning for a religious home is, he acknowledges, very much tied to the loosening-up of Irish life in the 1960s and the 1970s: "After decades of sexual and political obscurantism, Ireland had started to change in the $1960 \mathrm{~s}$ ", reflecting that his rejection of convention "felt 
rebellious at the time, but I realise now many others felt the same. My revolt, then, was conventional in itself" (p. 19). Dunne's historical situation of being between eras leaves him without a sense of rootedness in secular time, let alone eternity: "Unable to make the old and the new fit, I was like a hinge attached loosely to each" (p. 18) ${ }^{14}$.

Unsurprisingly, what troubles him most is regulation: it is the rigorism and legalism of the Irish church that Dunne cannot accept. The pervasive, unquestioned grip of the Catholic Church as an informing spirit in all aspects of Irish social and political life was at last beginning to relax, in the 1960s - a process that Louise Fuller has memorably described as "the undoing of a culture ${ }^{15}$ ". As Dunne came of age, Catholicism in Ireland was shifting away from its highly public identity, and moving more into the realm of a personal faith. The easing of censorship mean that young writers in the 1970s, such as Dunne, were inspired by writers like John McGahern and Edna O'Brien, whose books depicted the life-killing, inhibiting aspects of Catholic restriction. Even among Irish Catholics who remained in the church, a previously unimaginable level of religious debate became possible in the wake of Vatican II.

The poet's continuing objection to church authority and teaching underscores a significant difference between Augustine and Dunne. In the patristic conversion, the saint desperately wishes to align himself with orthodoxy and the rules of the church; Dunne's postmodern conversion is in many ways a matter of setting aside and moving past precisely those elements. His resistance to regulation remains a problem to the end; "by temperament", he writes in closing, "I cannot be rule-bound" (p. 71). His resolution comes in finding a space, that of contemplative silence, in which the many rules of the institutional church can be set aside as so much underbrush, in favor of a spirituality "rooted in prayer and silence rather than in structures and in rules" (p. 47).

Nonetheless, there are times when Dunne the seeker does, in fact, crave structure and conviction. "I desperately wanted to believe in something", he writes. "Without a religious belief or a confident atheism, I felt adrift, and afraid". Such a period of trying on various systems of belief is central to the "wandering" phase of the journey. As Leigh notes, "The use of a directional image [seen in the 'road' of the title] implies, of course, that the storyteller is going somewhere, even if it is, as Eliot says 'to arrive where we first started and to know the place for

14. Augustine, too, wrote in a period of enormous social change - the era of late antiquity, which witnessed the final collapse of Rome.

15. Louise Fuller, Irish Catholicism Since 1950: The Undoing of a Culture, Dublin, Gill and Macmillan, 2002. Other important studies of the changed religious environment in Ireland are Tom Inglis, Moral Monopoly: The Catholic Church in Modern Irish Society, Dublin, Gill and Macmillan, 1987; Mary Kenny, Goodbye to Catholic Ireland, Dublin, New Island Books, 1997; and J. H. Whyte, Church and State in Modern Ireland, 1923-1979, Dublin, Gill and Macmillan, 1980. 
the first time'... What it does not immediately indicate is what happens in all these modern stories of the wandering self (as in Augustine's Confessions) is that, for most of the story, the direction is the wrong one. [...] what intrigues many readers of spiritual autobiography is that the journey consists primarily of wrong turns and dead ends ${ }^{16}$." And again, what Dunne at first wanted to find in all of these writers is a total, cohering system: "Whether in Marxism, Humanism, or Buddhism, I had an interest in systems of thought that gave structure and sense to life" (p. 21). He hungers for, but cannot find, an intellectual underpinning to life, remarking that "Oddly, I had little trouble with the idea of prayer and a great deal of trouble with the intellectual idea of God" (p. 47).

To address his spiritual hungers, Dunne looks within; he would surely agree with what the philosopher Charles Taylor said of Augustine's faith, that the step "toward inwardness is a step toward God ${ }^{17 "}$ Yet, although the poet insists that his journey is interior, his journey is in no way undertaken alone. He pursues an exceptional range of literary mentors. Literature is central to his pursuit of a spiritual wholeness: "My reading pushed me beyond the forms in which religion was presented" (p. 20). In this context, we might note another of the stylistic oddities of The Road to Silence, which further contributes to the sense that it reads like a translation. In the entire book, there are exactly two sentences of spoken dialogue, both unremarkable: after Fr. Joseph has given Dunne the key to his room at Mount Melleray, we read, "I'll see you after tea, he said. 'There's a few biscuits on a plate in the kitchen if you're hungry until then'” (p. 41).

His conversation with authors, in contrast, is extensive. Writers whom he quotes from or alludes to in the course of the book include Matsuo Bashō; Albert Camus; Fyodor Dostoevski; the travel writer Patrick Leigh Fermor, who wrote a 1957 book on monastic life, A Time to Keep Silence; Eric Gill; Julian of Norwich; Carl Jung; D. H. Lawrence; Karl Marx; John McGahern; Thomas Merton, who, though much cited, is perhaps not present to the extent one would expect; Vladimir Nabokov; Flannery O'Connor; Henry David Thoreau; Simone Weil, to whom he is especially drawn; and Ludwig Wittgenstein.

Dunne clearly considers Thomas Merton to be a sort of mentor, quoting him on numerous occasions. His first trip to Mount Melleray is taken under the aspect of Merton:

I was very excited by the prospect of my visit. My enthusiasm was fuelled by my general interest in spirituality and also by my love for the work of Thomas Merton, the American monk and poet. I had become

16. Leigh, Circuitous Journeys, p. 2-3.

17. Charles Taylor, Sources of the Self: The Making of the Modern Identity, Cambridge, Harvard University Press, 1989, p. 132. 
aware of Merton in 1982. During that year, one of the most despairing I had known, I spent a long period in hospital and found that many of the books which normally pleased me were suddenly of no interest at all. Only two writers fired me: the novelist Francis Stuart, and Thomas Merton. In Merton, I found someone who had asked some of the same questions as myself and who had found answers in a life spent in silence on the margin of American society. Like the monks in Mount Melleray, he was a Cistercian (p. 34).

Despite this sympathy and admiration, Dunne notes that he disliked the "triumphalism" of Merton's early writings, "and especially disliked his autobiography, The Seven Storey Mountain" (p. 34). It is also notable that Dunne's attraction to Merton's work is highly selective; for instance, he never mentions Merton's activism and commitment to social justice. Indeed, he quotes with approval Merton's remark that monks are "are deliberately irrelevant. We live with an ingrained irrelevance that is proper to every human being"' (p. 76). The psychology of vocation, and the physical and intellectual demands of monastic life, fascinate Dunne; he says, near the end of the memoir that "There is a monk in everyone: solitary, silent, and faced with questions of belief and eternity, and with the need to know God" (p. 77). But he picks and chooses which aspects of Merton's thought he attends to, and which path he can follow in his own life.

During his period of searching, Dunne attends his first Protestant services where he feels acutely aware of the historical baggage that accompanies the religious divide. It is in this period that he encounters his first experience of a formalized recognition of silence as a spiritual presence among the Society of Friends. He writes that, "while I could argue intellectually about the social role of religion in Ireland, it seemed that the very core of religious belief did not happen in such arguments but at what happened when I sat in silence at such meetings" (p. 30). Moreover, he adds, Quakerism "seemed to accommodate uncertainty". It is a sign of sign of Dunne's growing spiritual maturity that he comes to understand doubt and ambiguity not as a failure of faith, but as essential elements of his religious journey - in a sense, a Keatsian willingness to embrace mystery itself.

Dunne's journey takes a decisive turn in the next chapter. At this point, he is getting by as a freelancer, following the method of simply coming up with article ideas and proposing them to editors. He has a working relationship with the editor of the Sunday Tribune, to whom he pitches the idea of an article on Mount Melleray. As in most spiritual autobiographies, caprice and circumstance play a significant role: his opportunistic assignment leads him to places he never expected. This, too, is a common feature in the genre, an admission by the author, that he or she is not the only one writing the story. We understand that Dunne is 
meant to have found the Trappists; the Sunday newspaper assignment may be an unexpected source, but so was St Augustine's tolle lege moment in the garden.

The next two chapters are essentially journalistic. In one, Dunne describes the rituals and practices of monastic life, clearly tinged by admiration and attraction. Chapter 5 is still more journalistic, concerning itself with the origins and history of Mount Melleray. The monastery has strong ties to Irish history - Daniel O'Connell frequently made retreats there - and provided generous help to the poor during the years of the Famine.

The sixth and seventh chapters conclude Dunne's faith journey, to the extent that there is a clear conclusion. It would not be true to say that Dunne returns to the faith of his childhood. "No matter how regularly I attended church", he writes, "I never gained a sense of my search having come to an end" (p. 65). As the last chapter opens, he says of his relationship to Mount Mellleray that, "while I loved the world I found there, and while I recognized that such a world was grounded in a particular set of religious beliefs, I still could not bring myself fully to practice as a Catholic" (p. 65). His experiences at Melleray, and later, his experiences at the urban retreat center of Saint Gervais in the heart of Paris, change that. His visits to Melleray, he writes, "made many things clear", continuing that

I had not become a compliant Catholic; rather, I saw faith practised in a way that was unsullied by the weight of social pressure and argument, and I felt that at the heart of the monastery lay an experience and faith that matched the heart of my own life, and that could be sustained despite the occasional absurdities of the church as a social entity. It was an interior experience and it changed everything (Emphasis added, p. 71).

But after his experience of the retreat at St Gervais, the longstanding resentments and struggles with Catholicism lose their potency for Dunne, and he is able to say that

I had discovered once again that, despite all my arguments with the Catholic Church, there are signs of tremendous tenderness, excitement and promise. Some are social; some are liturgical; some are monastic. The best of them begin in an interior space that has been shaped by silence and prayer (p. 69).

Nevertheless, Dunne does not become "a compliant Catholic"; to the end, he continues to look for spiritual sustenance in traditions other than Catholicism, including Quakerism, Buddhism, and the nearly extinct sect of Shakerism. "What Dunne found in Mount Melleray and Merton”, Andrew Auge has written, in his recent study of Catholicism and modern Irish poetry, "bore a close resemblance to what he found in the other religious traditions into which he delved - a profound 
commitment to silence as a means of acknowledging an ineffable Absolute and a posture that allows 'observed particulars [to] take on the mystery of revelation ${ }^{18}$ '”.

Perhaps paradoxically, despite the unashamed bricolage of his religious thinking, Dunne is surprisingly prescriptive in his summing up about how the journey inward is to be taken. He is certain that it needs to be a road to silence, a paring away of irrelevant dailiness and irrelevant speech. His spirituality is apophatic, averse to language and drawn to the direct experience of the presence of God. The words "center" and "core" recur again and again. Describing the Catholic ceremonies of his youth, he writes that "somehow in the centre of it, there was a sense that life had another element... It was a wordless centre" (p. 12). Of his time among Quakers, Dunne reports that "it seemed that the very core of religious belief did not lie in ... arguments but in what happened when I sat in silence at such meetings" (p. 30). Standing near the Blessed Sacrament at a Mount Melleray retreat, he reports "in the presence of the Eucharist, I felt in touch with a core of sacredness" (p. 59). Of monastic life, he observes, "monks do not escape the world but face it at its very centre which lies at the core of each person's life" (p. 61). In France, in a "worn church by the Seine" he learns "that prayer is not simply a matter of words but it is often wordless, gathering an accretion of quiet as it deepens and grows. I learned that I could keep this core of silence in my life just as this [monastic] order keeps it within the heart of Paris" (p. 69).

Whether or not Dunne intended it, it is hard for readers acquainted with Irish poetry to not hear, in his quest for interiority, resonances of Yeats's phrase "the deep heart's core" from "The Lake Isle of Inisfree". When Dunne speaks of the spiritually nurturing sound of flowing water, as an aid to contemplation, "one of those sounds that inhabits silence without destroying it" (p. 51), we recognize a clear suggestion of Yeats's line in the same poem, "I hear lake water lapping with low sounds by the shore".

Silence, for Dunne, leads to an experience of connectedness to the whole of creation: not to a sudden understandings, as in a Joycean epiphany, but rather, to an experience of primordial, unmediated awareness. These moments exist outside language; indeed, Dunne is mindful of the irony that he is a man of words, who at some serious level distrusts words, and believes that "Eloquence can hide more than it reveals" (p. 55). He writes that, "In a world wary of transcendence and religious meaning, the language used to express such experiences has either been trivialised or deadened" (p. 21). Later, he notes that "In religion, as in politics, there is a jargon to which my ears have been closed for many years. I found that I lacked the words for religious experience, and that the experience was more real

18. Andrew J. Auge, A Chastened Comnmunion: Modern Irish Poetry and Catholicism, Syracuse, Syracuse University Press, 2013, p. 220. 
than the language in which it is conventionally expressed" (p. 70). In the end, Dunne's deeply intuited spiritual epistemology could hardly be more different from that of Yeats: the elder poet may have glimpsed something elemental in the deep heart's core, but he quickly turned his back on it and went on to construct a fabulously complicated superstructure in words. Dunne, in contrast, rejects such accretions and stays with that core.

That core will have to be enough; we will never know what sort of memoirs Sean Dunne might subsequently have written, had he lived. The monastery, he says, "became a quiet haven to which I frequently retreated" (p. 65), but his writing life was tragically cut short.

It may be that the solace Dunne found in silence would, in time, have led him to undertake a more syncretic volume, one in which the centripetal tendencies of his spiritual life more specifically balances, and enters into dialogue with his life in the world. He suggests that such a move was underway in the book's closing paragraphs; there, he writes of his pursuit of silence in many different places and among many different groups, that his journey has been "a pilgrimage along a path that, like Basho's road to the far north of Japan, leads to a greater unity between what I am and what I do" (p. 79). Whatever shape the never-tobe written books might have taken, it seems certain that the silence that Dunne discovered at Mt. Melleray and elsewhere would remain, as his close friend and fellow poet Thomas McCarthy has written, his "enabling myth" ${ }^{19}$ ".

19. Thomas McCarthy, "Seán Dunne, Poet and Friend, 1956-1995" in Gardens of Remembrance, Dublin, New Island Books, 1998, p. 176. 